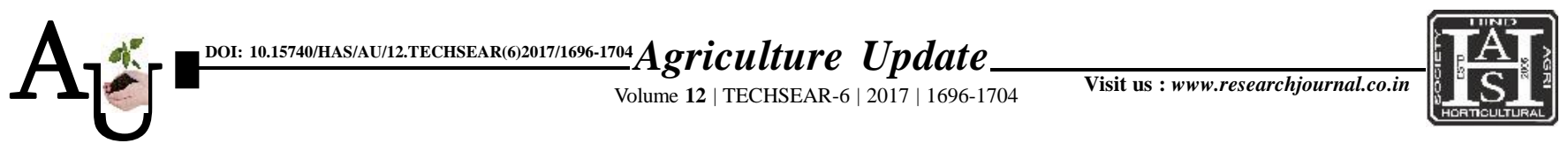

\title{
Research Article: Deciding sowing dates based on estimated evapotranspiration and water requirement and planning irrigation scheduling of lentil crop (Lens culinaris) using CROPWAT 8.0 model
}

\author{
口 JATOTH VEERANNA AND A.K. MISHRA
}

Article Chronicle : Received :

17.07.2017;

Accepted :

01.08.2017

KEY WoRds:

CROPWAT, Crop water requirement, Irrigation schedule, NIR, GIR, Sowing period

Author for correspondence :

\section{JATOTH VEERANNA}

Division of Agricultural Engineering, ICARIndian Agricultural Research Institute, NEW DELHI, INDIA Email: veerucae023@ gmail.com
SUMMARY : Due to over exploitation of available water resources, it has become very important to define appropriate strategies for planning and management of water in semiarid conditions for successful growing of Lentil crop (Lens culinaris) as it is highly profitable. To achieve effective water allocation and planning, the information about Lentil crop water requirements, irrigation withdrawals, soil types and climate conditions were gathered from the study area i.e. Anthanpur district of Andhra Pradesh (A.P). The main objectives of the study area were to estimate the Lentil crop water requirement (i.e., evapotranspiration) and deciding the proper sowing time in semi-arid agro climatic conditions of Ananthapur, A. P.To estimate the climatic water deficit, net irrigation requirement (NIR) and gross irrigation requirement (GIR) under different rain fed and irrigated conditions with six different growing dates with interval of 10 days starting from $1^{\text {st }}$ September to 20 October.The results showed that the best sowing dates were last week of September to $1^{\text {st }}$ week of October, which gives best utilization of rainfall as effective rain fall. The net and gross irrigation requirement (NIR and GIR) varied from a minimum to maximum as $69.7 \mathrm{~mm}, 110.3 \mathrm{~mm}, 78.2 \mathrm{~mm}, 119.4 \mathrm{~mm}, 114 \mathrm{~mm}$ and $165.9 \mathrm{~mm}$; respectively for all sowing dates. Thus, by adopting a proper sowing date and irrigation scheduling criteria, it is possible to save $49.7 \mathrm{~mm}$ of water as NIR for early sown crop. Hence, the Lentil crop can be successfully grown in the semi-arid condition of Anthapur, Kadapa, Kurnool district of A.P. as well as similar other areas in the Telangana and which often suffer from the want of water. Farmer can fetch high return by selling Lentils than other crops.

How to cite this article : Veeranna, Jatoth and Mishra, A.K. (2017). Deciding sowing dates based on estimated evapotranspiration and water requirement and planning irrigation scheduling of lentil crop (Lens culinaris) using CROPWAT 8.0 model. Agric. Update, 12(TECHSEAR-6) : 1696-1704; DOI: 10.15740/HAS/AU/12. TECHSEAR (6)2017/1696-1704. 